\title{
818 鋳造アルミニウム合金の衝撃引張特性に及ぼすDAS の影響 Effect of DAS on Impact Tensile Properties of Casting Aluminum Alloy
}

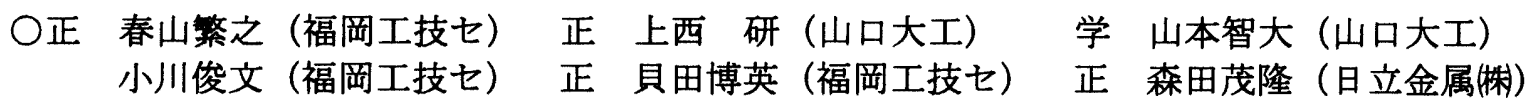

Shigeyuki HARUYAMA, Fukuoka Ind.Tech.center,3-6-1,Norimattu,Yahatanishi,Kitakyusyu,Fukuoka Ken KAMINISHI, Tomohiro YAMAMOTO, Yamaguchi University,2-16-1, Tokiwadai,Ube, Yamaguchi Toshifumi OGAWA, Hirohide KAIDA, Fukuoka Ind.Tech.center Shigetaka MORITA, Hitachi Metals,Ltd,11,Kinugaoka,Moka,Tochigi

Key Words : Aluminum Casting Alloy, Impact Strength, Dendrite Arm Spacing, Hot Isostatic Pressing

\section{1. 繚垔}

近年，渨境や安全に対する自動車産業への要求はますま す厳しくなってきている，そのため, 安全性, 低然費、リ サイクル性からの虾境への配慮が必須となってきている. この解決策の一つとして, リサイクル性に優机軽量で設計 自由度が高い鋳造アルミニウム合金が，自動車部材の衙慗 を受ける部分へ使用されはじめている，従って，䤲造アル ミニウム合金の街繁引張特性を正確に把握することが重要 な課題となり、これまでに, 上西らりにより衝撃荷重下にお ける AC4CH アルミニウム合金鋝物の DAS (Dendrite Arm Spacing）が引張強さに与える影㗽などの検討がなされてい る. 多くの場合, 組織の粗大化をもたらす凝固条件は同時 に，你の形成を助長する条件でもあるため DAS と釷造欠 陥を合わせて考唐する必要がある，そこで，本研究では， 引張型ホプキンソン棒法を応用した高精度衝撃試験装置を 用いて $\mathrm{AC} 4 \mathrm{CH}$ アルミニウム合金鋳物の鋳造欠宿を考慮し た DAS と引張強度特性について検討を行った。

\section{2. 实駼方法}

\section{1 侙钽片}

本研究で用いた $\mathrm{AC} 4 \mathrm{CH}$ アルミニウム合金鋳物の化学成 分を表 1 に示寸．また，試駼片は長手方向が負荷方向と平行 になるように採取し，鋳造ブロック底から採取位置までの距 離 DBB（Distance from the Block Base）を 4 種類に分類し た.

\section{2 侙确片製作}

鋳造欠陥を考慮するため図 1 に示す条件で HIP（Hot Isostatic Pressing）処理を実施し鋳造欠陥を除去した試験 片及び HIP 処理を行わなかった試験片をそれぞれ，次の条 件で熱処理を行った $\left(540^{\circ} \mathrm{C} \times 4 \mathrm{~h}\right.$ の溶体化後温水冷し $145^{\circ} \mathrm{C}$ $\times 4 \mathrm{~h}$ の時効処理). その後, 図 2 に示卞試験片形状・寸法に 加工を行った. 図 3 にそれぞれの内部欠陷の状態を示す.

Table.1 Chemical composition

\begin{tabular}{c|ccccc}
\hline & $\mathrm{Si}$ & $\mathrm{Mg}$ & $\mathrm{Fe}$ & $\mathrm{Ti}$ & $\mathrm{Sr}$ \\
\hline $\mathrm{AC} 4 \mathrm{CH}$ & 7.19 & 0.35 & 0.14 & 0.06 & 0.01 \\
\hline
\end{tabular}

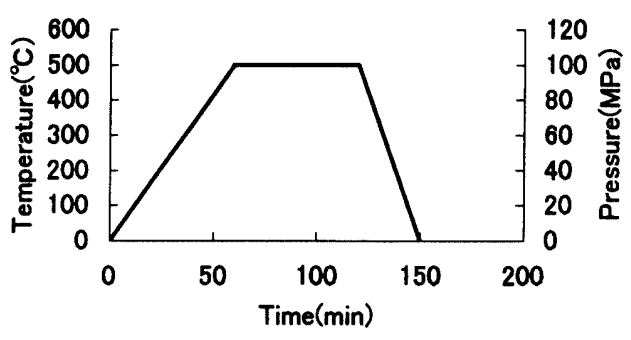

Fig. 1 HIP condition

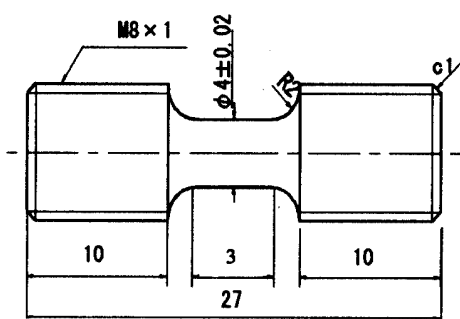

Fig.2 Specimen

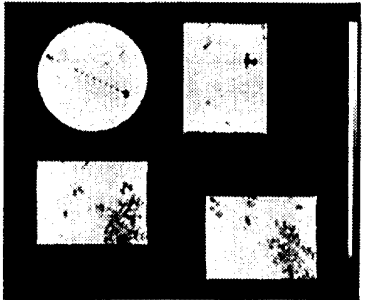

(a) non-HIP

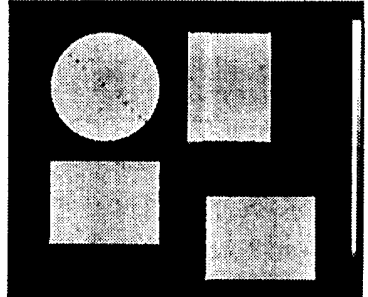

(b) HIP
Fig.3 Multi planner construction image

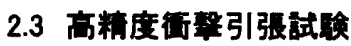

高精度衙擊引張試験装置の概略を図 4 に示す，本装置は， 横山式試験装置 2)を応用したもので，入力棒，銃身，打出し 円管および計測系から粠成されている．入力棒及び打出し 円管はそれぞれ Al2017·T4 合金を用いている.

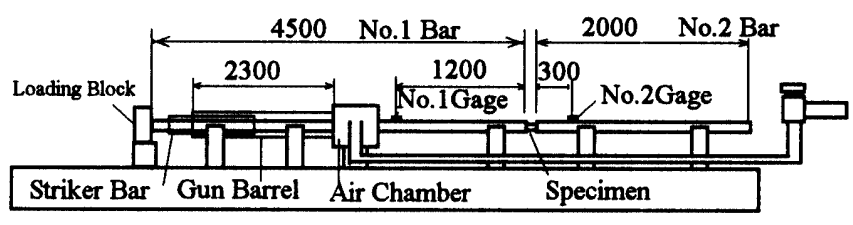

(Dimenvions :man)

Fig.4 Impact tensile test system

\section{3. 实踔結果及び考察

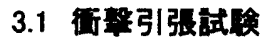

本実験で得られた衙慗引張試験の典型的なオシロスコー プ波形を図 5 に示す。このオシロスコープ波形の入射波, 反 射波，透過波を一次元波動伝播理論に基づき計算処理するこ とにより動的引張応力ーひずみ線図を求めた。また，HIP 処理有り, HIP 処理無し試験片の衝撃引張試験により得ら れた引張強さおよび伸びを表 2 に示す。

〔No.02-05〕日本機械学会材料力学部門講演会講演論文集〔2002-10.12 - 14,宇部市〕 


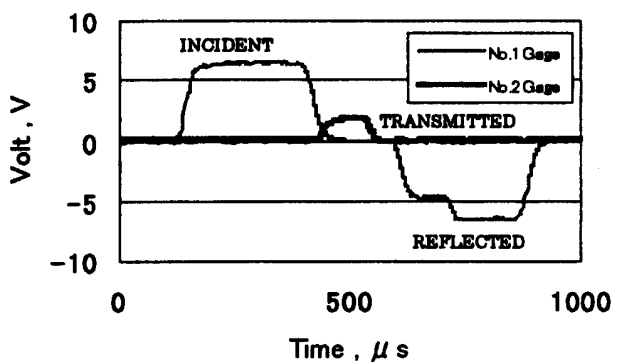

Fig. 5 Oscilloscope records from impact tensile test

Table.2 Experimental results

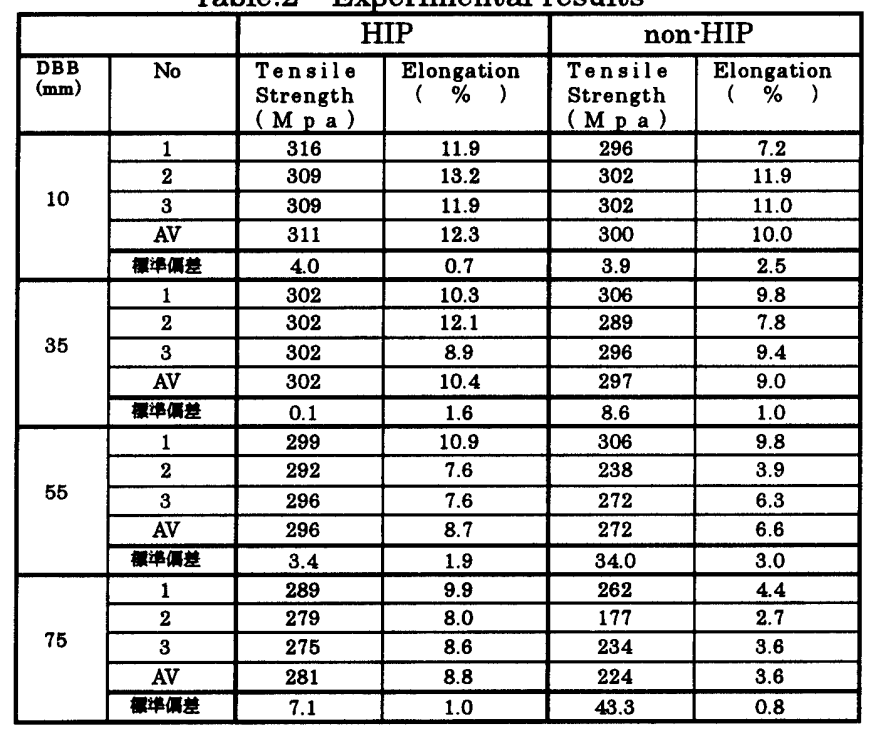

全ての採取位置において引張強さ及び伸びは HIP 処理有 りの方が HIP 処理無しより高い值を示した．また，HIP 処理 有り無しともに, DBB が大きくなるにつれて引張強さ，伸び の值が低くなる傾向を示した. 更に, 表 2 より HIP 処理有 りでは，各 DBB における引張強さの值のばらつきはあまり 見られないが, HIP 処理なしでは, DBBが大きくなるにつれ 值のばらつきが大きくなっていることが分かる。

図 6 にDBBがそれぞれ (a) $10 \mathrm{~mm}$ と (b) $75 \mathrm{~mm}$ のミクロ写真を 示す．採取位置によりデンドライト組織の間隔が大きく異 なっており，DBBが小さくなるにつれデンドライト組織は微 細化されていることが分かる. 図 7 の関保を表 2 中のDBB に 代入し DAS と引張強さ，伸びの関係に整理すると図 8, 図 9 が得られる。

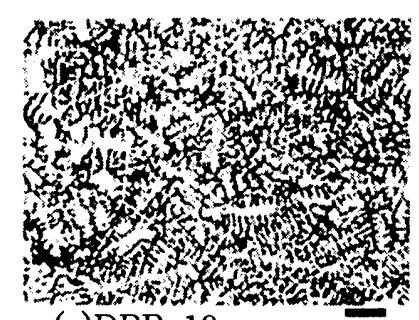

(a) $\mathrm{DBB}=10 \mathrm{~mm} \quad 200 \mu \mathrm{m}$

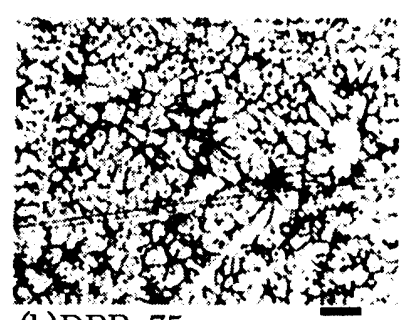

(b) $\mathrm{DBB}=75 \mathrm{~mm} \quad 200 \mu \mathrm{m}$
Fig. 6 Microstructures

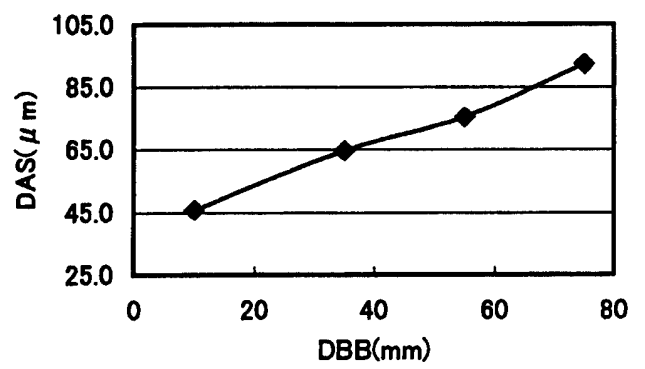

Fig. 7 Relationship between DBB and DAS
図 8,9より HIP 処理有り, HIP 処理無しともにDAS が大 きくなるにつれて，引張強さ及び伸びが低くなっているこ とが分かるが, HIP 処理無しではその低下がより大きくなっ ている. この HIP 処理有りと HIP 処理無しでの各 DAS にお ける值の差が欠陥による影㗽であると思われる.図10にDAS と欠陷面積率の関係を示す。このように鋳造欠宿は引張強 さ，伸びの低下とそのばらつきに与える影勧が大きいこと が分かった。

以上のことから, $\mathrm{AC} 4 \mathrm{CH}$ アルミニウム合金鋳造の引張強 さ及び伸びは，DAS の大きさに依存するが久陷による影警が より大きいことが分かった。

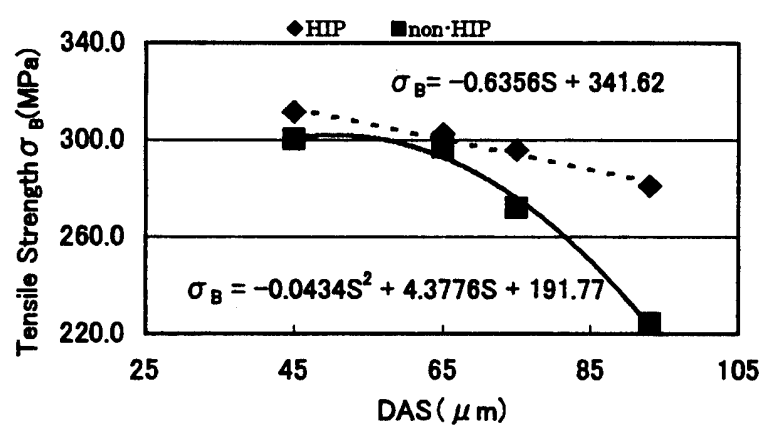

Fig. 8 Relationship between DAS and tensile strength

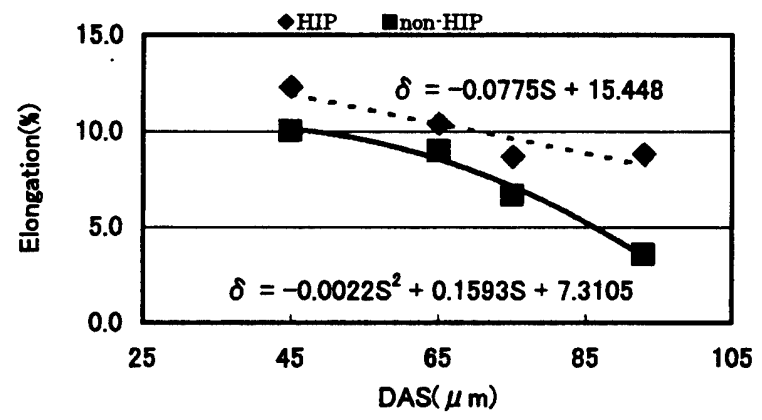

Fig. 9 Relationship between DAS and elongation

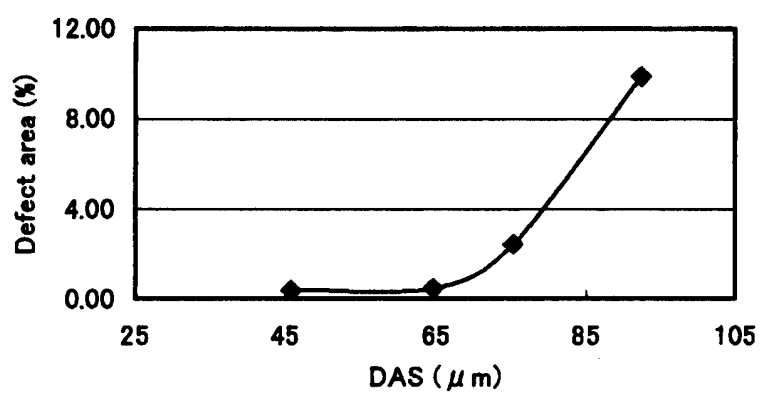

Fig. 10 Relationship between DAS and defect area

\section{4. 結言}

（1） $\mathrm{AC} 4 \mathrm{CH}$ アルミニウム合金鋳造の引張強さ及び伸び は, DAS の大きさに依存するが欠陷による影敏がより 大きい.

（2）鋳造欠宿は引張強さ，伸びの低下とそのばらつきに 与える影㗽が大きい.

\section{5. 参考文献}

1. 上西研 : 機講論, 熊本地方講演会, No. 018-2, (2001)

2. 横山隆 : 軽金属, 52 巻 6 号, (2002), 262-268 